\section{Divestiture strategy, CEO power and firm performance}

Divestiture strategy

Rayenda Khresna Brahmana

Faculty of Economics and Business, Universiti Malaysia Sarawak, Kota

Samarahan, Malaysia

Hui-Wei You

School of Management, Zhejiang University, Hangzhou, China and Faculty of

Economics and Business, Universiti Malaysia Sarawak,

Kota Samarahan, Malaysia, and

Xhin-Rong Yong

Faculty of Economics and Business,

Universiti Malaysia Sarawak, Kota Samarahan, Malaysia

\begin{abstract}
Purpose - This study aims to examine the moderating role of chief executive officer (CEO) power on the relationship between divestiture strategy and firm performance by framing the relationship under the agency and power circulation theories.
\end{abstract}

Design/methodology/approach - This study focuses on a sample of 319 non-financial public-listed companies in Malaysia from the year 2012-2016 and estimates the model under two-step generalized method of moments panel regression to eliminate the endogeneity issue.

Findings - The results show that divestiture strategy decreased the firm performance. Meanwhile, greater CEO power changed that divestiture effect but still failed to increase the performance. This study also indicates the CEO power strengthens the relationship between firm performance and divestiture.

Research limitations/implications - The overall findings show that the positive moderating role of CEO power on the relationship between divestiture and performance. This research confirmed the agency and power circulation theories by showing that CEO power can make divestiture strategy works. However, the moderating plot tells different. CEO power may strengthen the relationship between divestiture and performance; it fails to boost up the performance in overall. Therefore, this study is about CEO power on the strategic decision and gives a good implication for corporate governance concerning the impact of $\mathrm{CEO}$ power on the organization's alignment process.

Originality/value - This study examines the effect of CEO power on the performance of divestiture strategy implementation by contesting the agency and power circulation theories within an emerging country context.

Keywords Firm performance, Corporate governance, Corporate strategy, Agency theory, CEO power, Divestiture strategy, Power circulation theory

Paper type Research paper

\section{Introduction}

Due to the financing constraints from the external capital market, the firm acquires funding by selling off their business unit or subsidiaries (Kolev, 2016). Through this defensive, the firm does not only receive the additional cash flow but also transforming into a more competitive organization (Kolev, 2016; Konara and Ganotakis, 2020). The stewardship and resource-based view theories posit that divestiture strategy is a defensive choice for a firm to
Received 8 April 2020

Revised 15 July 2020 15 July 2020

2 September 2020

Accepted 8September 2020 